\title{
LINEAR AND NONLINEAR WEIGHING OF PROPERTY FEATURES ${ }^{1}$
}

\author{
Anna Barańska, D.Sc., Ph.D. \\ Faculty of Mining Surveying and Environmental Engineering \\ AGH University of Science and Technology \\ e-mail:abaran@agh.edu.pl
}

Determining the weights of market features of real estate in explaining their prices is one of the basic objectives of market analysis, performed as part of the property value estimation process. In practice, property appraisers usually settle for basic methods of determining weights, for example based on the principle of ceteris paribus or on the basis of linear correlation coefficients. The article proposes the use of curvilinear correlation coefficients for this purpose; an attempt of such use was made and the obtained results were compared with the weights determined on the basis of linear correlations. The conducted analyses proved that the inclusion of curvilinear correlations at the stage of market analysis, allows for extracting a greater number of features recognized as price-creating, i.e. leads to a smaller loss of market information and is a more reliable tool for determining the weights of attributes in price explanation.

Keywords: real estate market analysis, real estate features weights, linear and non-linear correlation.

JEL Classification: C00, C01, C13, C15, C50, C51, L85, R30.

Citation: Barańska A., 2019, Linear and Nonlinear Weighing of Property Features, Real Estate Management and Valuation, vol. 27, no. 1, pp. 59-68.

DOI: $10.2478 /$ remav-2019-0006

\section{Introduction}

Determining the weights of market features of real estate in explaining their prices is one of the basic objectives of market analysis, performed as part of the property value estimation process. Many authors have researched this issue (DOSZYŃ, GNAT 2017; GACA, SAWIŁOW 2014 etc.). In practice, property appraisers usually settle for basic methods of determining weights, for example based on the principle of ceteris paribus. A slightly more advanced tool used for this purpose is correlation analysis - however only in relation to classic linear correlations, possibly including rank correlations (DOSZYŃ 2017; GACA, SAWIŁOW 2014), due to the qualitative character of most of the price-making features of real estate. This approach tacitly assumes the homogeneity of the analyzed real estate market, i.e., a proportional change in prices along with a change in the value of a given property feature. Unfortunately, reality is most often more complex and such an assumption may cause large errors in estimating the weights of market characteristics.

The monotonic, but non-uniform, and therefore non-linear variability of price along with a change in the value of a given feature has an impact on the complexity of the identified market relations. It may also be the result of suboptimal or even incorrect scaling of market features, which most often assumes that changing the value of a feature in a specific direction (increase or decrease) will always cause an increase or decrease in the price. This does not have to be the case, and relevant examples can be found, for example, in a study of the price relation with the distance from the center of the local

\footnotetext{
${ }^{1}$ The task was carried out within the scope of statutory research in Department of Geomatics, Faculty of Mining Surveying and Environmental Engineering, AGH Krakow, Poland.
} 
market in question, without reference to local fashions for specific locations. We often deal with such situations in big cities.

In the first case, when it comes to the monotonic, but non-linear relation - one should consider one of the elementary non-linear monotonic functions, such as the exponential function, logarithmic function, tangent, homographic with the appropriate domain, or even the third degree polynomial with appropriate parameters. It is also possible to consider a function composed of several linear functions, i.e. broken regression, which will allow to take into account, for example, price stability for some range of the value of a given feature, which is part of its entire volatility. The simplest example can be price stability within a few months in the middle of the selected period from which market data originated, constituting the basis for market analysis (Figure 1).

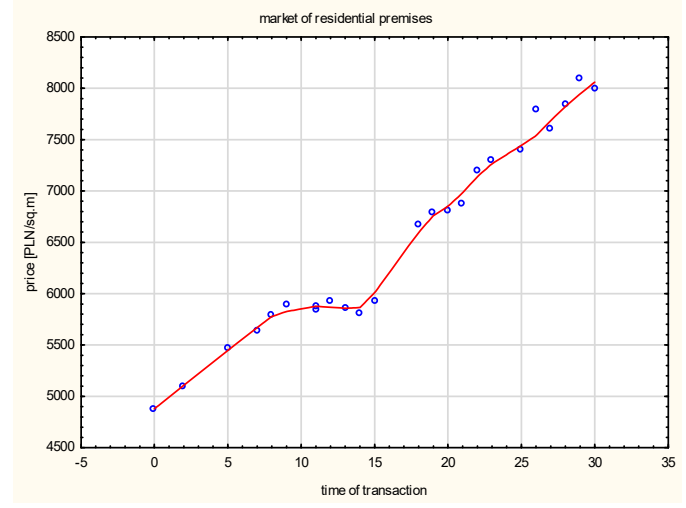

Fig. 1.Trend of changes in the prices of residential premises. Source: own study.

In the second case, when the identified non-linear relation of the price with the selected market feature results from its unbalanced scaling, a function that has one or more extremes, such as a square function or other polynomial functions, may be useful (Figures 3 and 5).

Such an approach is more likely to be adequate to reality than generalization by means of linear correlations or even rank correlations that, de facto, also examine linearity, although with reference to ordinal variables. The author poses a thesis that we make a smaller mistake by using quantitative nonlinear indexes to qualitative variables calibrated numerically than indicators from the assumption more suitable for such types of variables, but limited to the study of linear relationships. Of course, we assume that every effort is made to achieve the most objective characteristics of real estate at the stage of the characterization of the local market.

The article proposes the use of curvilinear correlation coefficients, corresponding to selected functions, to calculate the weights of market characteristics. At the same time, exemplary analyses and calculations are presented on a specific example and the obtained results are compared with weights determined on the basis of Pearson's linear correlations.

\section{Curvilinear correlation}

The curvilinear correlation coefficient $q$ is a generalization of the commonly used Pearson correlation coefficient $r$ and is calculated according to the following formula:

$$
q=\sqrt{\frac{\sum_{i=1}^{n}\left(f\left(x_{i}\right)-\hat{y}\right)^{2}}{\sum_{i=1}^{n}\left(y_{i}-\hat{y}\right)^{2}}}=\sqrt{1-\frac{\sum_{i=1}^{n}\left(y_{i}-f\left(x_{i}\right)\right)^{2}}{\sum_{i=1}^{n}\left(y_{i}-\hat{y}\right)^{2}}}=\sqrt{\frac{W S K}{C S K}}=1-\sqrt{\frac{N S K}{C S K}}
$$

where:

$x_{i}$ - empirical value of the independent random variable (property attribute) for observation $i$,

$y_{i}$ - empirical value of the dependent random variable (property price) for observation $i$,

$f\left(x_{i}\right)$ - model value of dependent variable for observation $i$,

$\hat{y}$ - the average value from the empirical values of the dependent random variable,

$n$ - random sample size,

$\operatorname{CSK}=\sum_{i=1}^{n}\left(y_{i}-\hat{y}\right)^{2}-$ the total sum of squares, i.e. the total dispersion of a dependent variable in relation to its average value,

$W S K=\sum_{i=1}^{n}\left(f\left(x_{i}\right)-\hat{y}\right)^{2}=\sum_{i=1}^{n}\left(\left(y_{i}-\hat{y}\right)-\left(y_{i}-f\left(x_{i}\right)\right)\right)^{2}$ - the sum of squares explained by the regression model, 
$N S K=\sum_{i=1}^{n}\left(y_{i}-f\left(x_{i}\right)\right)^{2}=\sum_{i=1}^{n} \delta_{i}^{2}-$ the unexplained sum of squared deviations of the regression model, illustrating the part unexplained by this model.

The value of $q$ is equal to the Pearson correlation coefficient $r$ when $f$ in Formula (1), in general two-dimensional non-linear regression, is a linear function. Its square $\mathrm{q}^{\wedge} 2$ is the coefficient of determination corresponding to the estimated model, adjusted to the dependence of the price on the selected property attribute. The complement to the unity of its value is the so-called mismatch factor (coefficient of non-conformity) of the model:

where:

$$
\varphi^{2}=1-q^{2}=\frac{\sum_{i=1}^{n}\left(y_{i}-f\left(x_{i}\right)\right)^{2}}{\sum_{i=1}^{n}\left(y_{i}-\hat{y}\right)^{2}}
$$

$q^{2}$ - coefficient of determination for the model describing the dependence of the price on the selected feature,

other designations as in Formula (1).

Both coefficients $q^{2}$ and $\varphi^{2}$ take values from the range $[0,1]$.

\section{Research problem}

The research material in this study was a set of data from the market of land properties for development from the Limanowa municipality. The created database has 63 properties, and its elements have been described using as many as 21 features that were identifiable. The list of features can be found in Table 1 .

Before proceeding to the proper analyses resulting from the purpose of this study, the time effect on the price level was analyzed. Due to price stability in the time period considered - correlation analysis was performed on transaction prices.

List of properties of real estate considered on the construction land market

Table 1

\begin{tabular}{cccc}
\hline No. & Real estate feature & No. & Real estate feature \\
\hline 1 & Destination in the local plan & 11 & Fashion for location \\
\hline 2 & Legal restrictions & 12 & The basic function \\
\hline 3 & The type of land right & 13 & Water supply network \\
\hline 4 & Rights share & 14 & Energy network \\
\hline 5 & Chattel mortgage & 15 & Gas network \\
\hline 6 & Landform & 16 & Sewer network \\
\hline 7 & Insolation & 17 & Total infrastructure \\
\hline 8 & Communication access & 18 & Access road \\
\hline 9 & Location of the property & 19 & Surroundings \\
\hline 10 & The shape of the plot & 20 & Development \\
\hline & & 21 & Surface area \\
\hline & & Source: own study
\end{tabular}

\subsection{Graphic depiction of price dependence on individual property features}

In the first stage of analyses, a series of price scatterplots were performed for each feature highlighted on the examined real estate market. The volume of this study does not allow for the inclusion of all graphs, which there are 21 of in total. Therefore, only a few examples are provided to illustrate the choice of elementary non-linear functions describing the dependence of price on the selected attribute (Figs. 2-5).

Least squares estimated lines (LSM) were applied to the scatterplots, i.e. without suggesting any specific functional dependence. The specific functions were selected only on the basis of the LSM line from elementary functions. On the presented diagrams, the selected functions were represented by the exponential function (Fig. 2), the quadratic function (Figs. 3 and 5) and the homogeneous function (Fig. 4).

Some of the plots did not give any basis for matching any nonlinear dependence or because the value of a given feature is too small (only two values - example in Figs. 6 and 7) or the straight line 
character of the regression line determined by the least squares method. The list of matching basic non-linear functions, i.e. two-dimensional regression, is presented in Table 2.
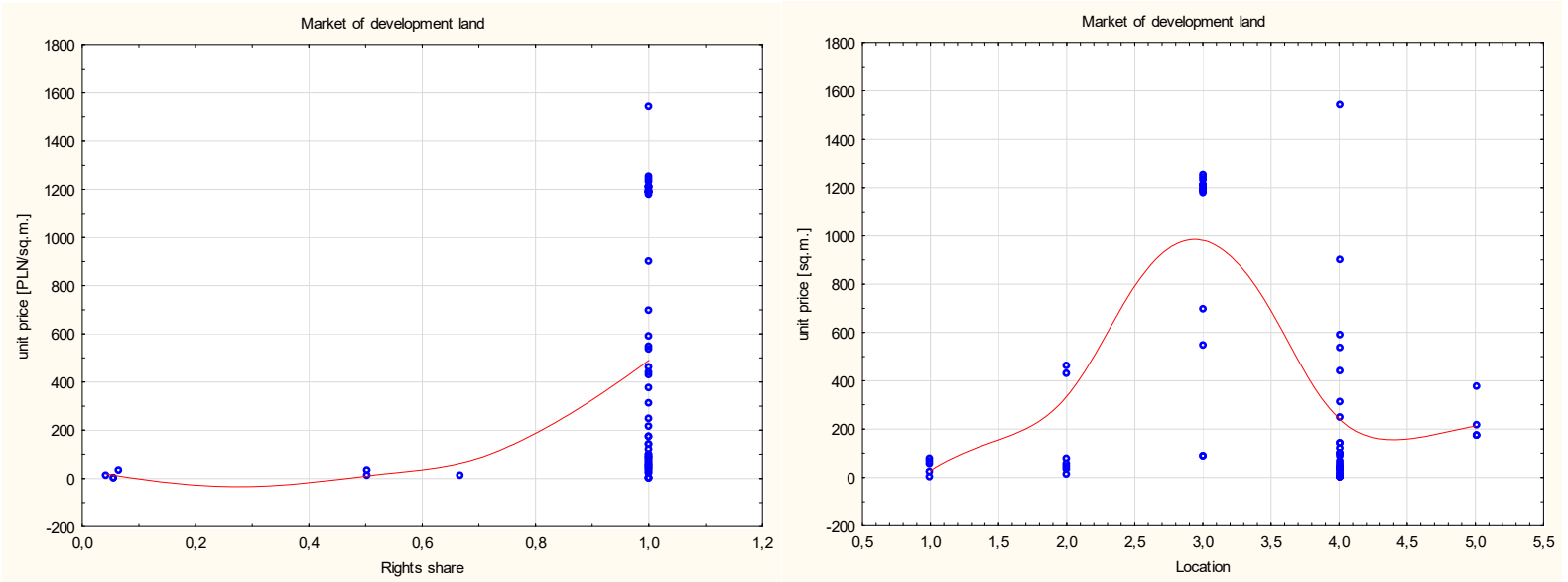

Figs. 2 and 3 Relationship between prices of construction land and the share of rights to the land as well as the location of the property. Source: own study
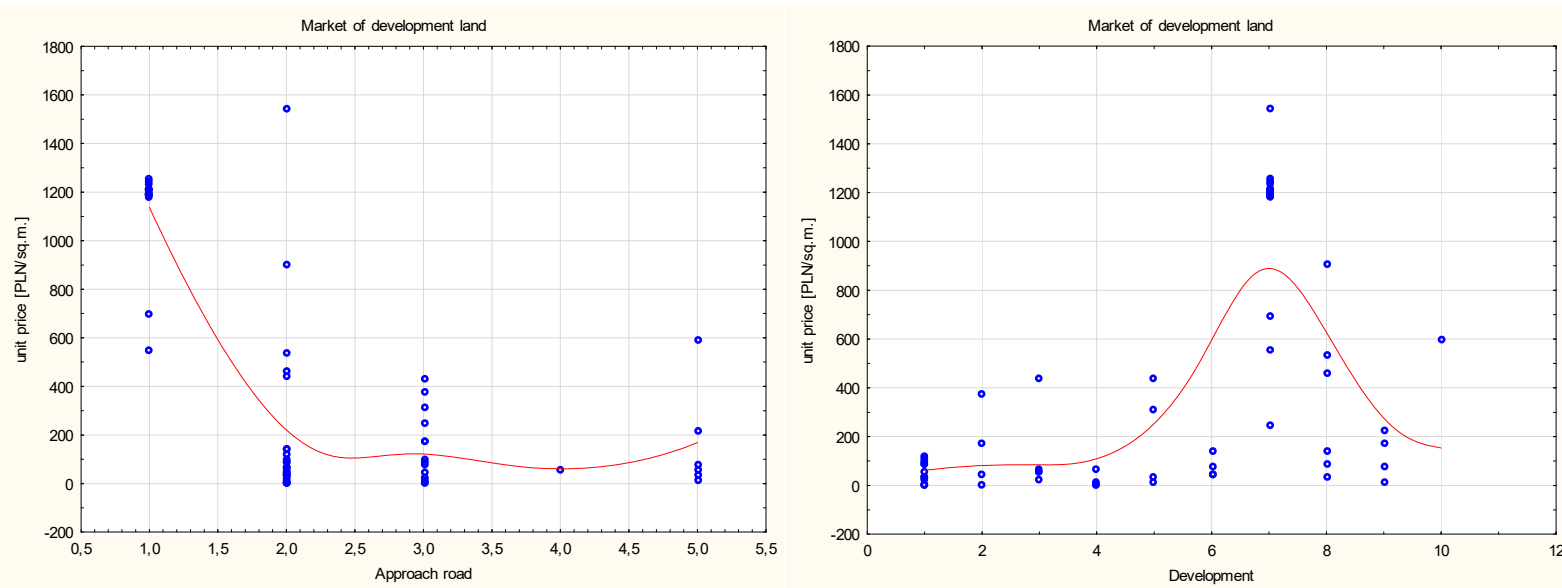

Figs. 4 and 5 Relationship between prices of construction land and the type of access road as well as the development of the surroundings. Source: own study
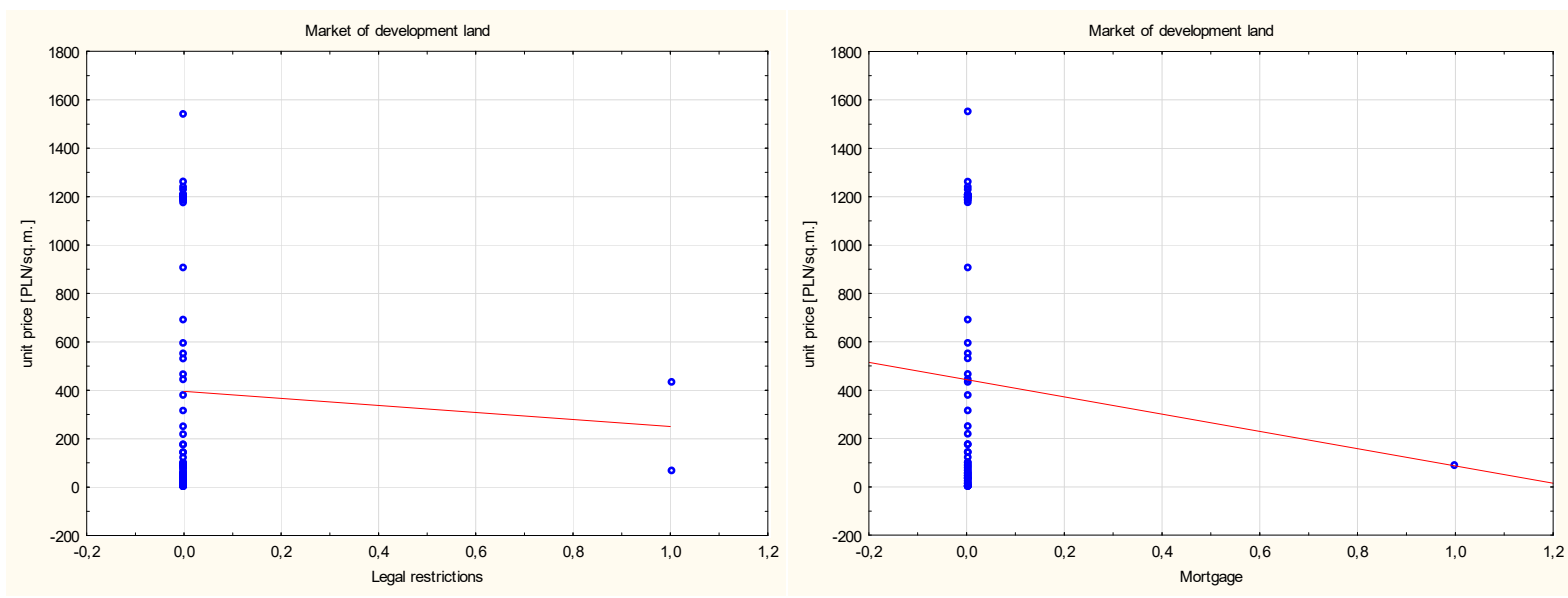

Figs. 6 and 7 Relationship between prices of construction land and the legal restrictions as well as the chattel mortgage. Source: own study 
Table 2

List of matching elementary non-linear functions

\begin{tabular}{|c|c|c|}
\hline No. & Function name & Function form \\
\hline 1 & quadratic function & $y=a+b \cdot x+c \cdot x^{2}$ \\
\hline 2 & the third degree polynomial & $y=a+b \cdot x+c \cdot x^{2}+d \cdot x^{3}$ \\
\hline 3 & exponential function & $y=a+b \cdot \exp (x)$ \\
\hline 4 & logarithmic function & $y=a+b \cdot \ln (x)$ \\
\hline 5 & homographic function & $y=a+\frac{b}{x}$ \\
\hline 6 & \multirow{4}{*}{ trigonometric functions } & $y=a+b \cdot \sin (x)$ \\
\hline 7 & & $y=a+b \cdot \cos (x)$ \\
\hline 8 & & $y=a+b \cdot \operatorname{tg}(x)$ \\
\hline 9 & & $y=a+b \cdot \operatorname{ctg}(x)$ \\
\hline 10 & inverse trigonometric function & $y=a+b \cdot \operatorname{arctg}(x)$ \\
\hline
\end{tabular}

Source: own study

\subsection{Estimation of two-dimensional non-linear regression parameters}

As Formula (1) shows, in order to calculate curvilinear correlations, we must first obtain the model values of the selected function $f$. Therefore, we need to estimate its parameters. The problem of estimating nonlinear function parameters in general is non-trivial. However, due to the use of elementary functions only, which are linear due to parameters - the estimation comes down to the use of a known algorithm for estimating multiple regression parameters, described in many publications (CZAJA 2001; BARAŃSKA 2010 et al.). The only modification concerns the construction of the coefficients matrix $A, \mathrm{t}$, of the created system of linear equations $A X=C$. Matrix $A$ will have the dimension $(n \times u)$, where $n$ is the random sample size, i.e. the number of properties, and $u$ is the number of searched parameters of the selected non-linear function. Therefore, apart from the ones column, resulting from taking into account the absolute term in each function - the remaining columns will result from the transformations of the independent variable (selected attribute), according to the indications of function $f$. For example, for a square function, after the ones column, we will have $x$ and $x^{2}$ columns. They are, of course, modifications of the same, one random variable $x$, but in the applied algorithm they play the role of two separate independent variables.

The estimation process follows the known formulas (3)-(5):

$$
\begin{gathered}
A \cdot X=C \\
\hat{X}=\left(A^{T} \cdot A\right)^{-1} \cdot A^{T} \cdot C \\
\hat{C}=f(x)=A \cdot \hat{X}
\end{gathered}
$$

where:

$A=\left[\begin{array}{ccc}1 & x_{1} & x_{1}^{2} \\ 1 & x_{2} & x_{2}^{2} \\ \vdots & \vdots & \vdots \\ 1 & x_{n} & x_{n}^{2}\end{array}\right]$ - exemplary coefficients matrix with dimensions $(n \times u)$ of the system of equations $A \cdot X=C$, linear due to parameters (for the fuction $f$, in the form of a quadratic function, $u=3$ ), $X=\left[\begin{array}{l}a \\ b \\ c\end{array}\right]$ - exemplary matrix of unknown function parameters, here: for $f(x)=a+b \cdot x+c \cdot x^{2}$, with dimensions $(u \times 1)$,

$C=\left[\begin{array}{c}c_{1} \\ c_{2} \\ \vdots \\ c_{n}\end{array}\right]=\left[\begin{array}{c}y_{1} \\ y_{2} \\ \vdots \\ y_{n}\end{array}\right]$ - vector of empirical values of dependent variable (price), with dimensions $(n \times 1)$,

$x_{i}$ - empirical values of independent variable (real estate feature),

$y_{i}$ - empirical values of dependent variable (real estate price),

$\hat{X}$ - vector of parameter estimators of function $f$, with dimensions $(u \times 1)$,

$\hat{C}=f(x)$ - vector of model values of dependent variable, with dimensions $(n \times 1)$. 
We omit the description of the accuracy analysis in the estimation of model parameters, as it can be found in other publications (CZAJA 2001; BARAŃSKA 2010 and others). The essence of these analyses is to determine the determination coefficient of model $q^{2}$ from Formula (1).

\subsection{Correlation analysis}

The main part of the carried out calculations was the analysis of the correlation between each property feature and property price on the selected local market. These analyses were preceded by a feature redundancy test, carried out using Pearson's correlation, which is an inherent element of market analysis performed with statistical methods. It is worth mentioning here that by applying the classical principle of ceteris paribus to determine the weights of market characteristics - the redundancy of features is not examined, because this method would be completely ineffective.

On the investigated market of development lands, four features turned out to be redundant: the water supply network, electrical power network, gas network and sewage network. All of them showed very strong correlation (well above 0.80 ) with total infrastructure. Therefore, they have been eliminated from the calculations. Hence, the set of 21 features considered at the beginning (Table 1) has been reduced to 17 . Table 3 presents the functions selected on the basis of two-dimensional scatterplots for which the highest values of the curvilinear correlation coefficient (1) were obtained.

Table 3

Calculation of weight shares of land property features for development based on curvilinear and linear correlations

\begin{tabular}{|c|c|c|c|c|c|c|c|c|}
\hline$i$ & Real estate feature & Function price(feature) & $q_{i}$ & $q_{i}^{2}$ & $k_{i}\left(q_{i}\right)$ & $r_{i}$ & $r_{i}^{2}$ & $k_{i}\left(r_{i}\right)$ \\
\hline 1 & $\begin{array}{l}\text { Destination in the local } \\
\text { plan }\end{array}$ & quadratic function & 0.450 & 0.2021 & 0.065 & -0.352 & 0.1237 & 0.051 \\
\hline 2 & Legal restrictions & linear function & -0.068 & 0.0046 & 0.001 & -0.068 & 0.0046 & 0.002 \\
\hline 3 & The type of land right & exponential function & 0.297 & 0.0879 & 0.028 & 0.284 & 0.0804 & 0.033 \\
\hline 4 & Rights share & exponential function & 0.287 & 0.0824 & 0.026 & 0.280 & 0.0782 & 0.032 \\
\hline 5 & Chattel mortgage & linear function & -0.089 & 0.0080 & 0.003 & -0.089 & 0.0080 & 0.003 \\
\hline 6 & Landform & expone & 0.260 & 0.0675 & 0.022 & 0.257 & 0.0660 & 0.027 \\
\hline 7 & Insolation & quadratic function & 0.356 & 0.1270 & 0.041 & 0.281 & 0.0788 & 0.033 \\
\hline 8 & Communication access & $\begin{array}{l}\text { the third de } \\
\text { polynomi }\end{array}$ & 0.430 & 0.1847 & 0.059 & -0.239 & 0.0572 & 0.024 \\
\hline 9 & Location of the & quadra & 0.511 & 0.2613 & 0.083 & -0.072 & & 0.002 \\
\hline 10 & The shape of the plot & quad & 0.213 & 0.0452 & 0.014 & 0.078 & 0.0060 & 0.002 \\
\hline 11 & Fashion for location & quadratic function & 0.504 & 0.2536 & 0.081 & 0.495 & 0.2450 & 0.101 \\
\hline 12 & The basic function & quadratic function & 0.400 & 0.1599 & 0.051 & 0.128 & 0.0164 & 0.007 \\
\hline 13 & Total infrastructure & quadratic function & 0.478 & 0.2289 & 0.073 & 0.437 & 0.1907 & 0.079 \\
\hline 14 & Access road & homographic function & 0.818 & 0.6695 & 0.214 & -0.594 & 0.3524 & 0.146 \\
\hline 15 & Surroundings & quadratic function & 0.458 & 0.2094 & 0.067 & 0.023 & 0.0005 & 0.000 \\
\hline 16 & Development & quadratic function & 0.559 & 0.3121 & 0.100 & 0.525 & 0.2752 & 0.114 \\
\hline \multirow[t]{2}{*}{17} & Surface area & quadratic function & 0.361 & 0.1306 & 0.042 & -0.317 & 0.1008 & 0.042 \\
\hline & & & Sum: & 3.1329 & 1.000 & Sum: & 2.4167 & 1.000 \\
\hline
\end{tabular}

Source: own study.

Where the linear regression shows a better matching, or where the selection of a non-linear function is impossible due to technical reasons (too small differentiation of features), we assume linear dependence as optimal.

The first difference that we observe between the results of the linear correlation analysis and the curvilinear correlation analysis is a significant increase in favor of the latter for the general percentage degree of explaining the price variability in the examined real estate market. This can be seen in the sum values of correlation coefficient squares (sums of determination coefficients), found in the last row of Table 3. These totals indicate an increase in the identified degree of explaining the price dispersion by all considered features by about 30\% (from 2.42 to 3.13) for development land. Thus, it can be seen how the application of curvilinear correlations, even for the simplest functional variants, can improve the credibility of the determined weight shares of individual property features. In this 
case, we can talk about credibility, because the coefficient of determination, being a measure of the model's adjustment to the empirical data, can also be interpreted as the degree of reliability of the conclusions drawn on the basis of the model which it concerns. On the other hand, market features weights are a direct derivate of this matching, as they are determined according to a known formula (e.g. Czaja 2001):

$$
k_{i}\left(q_{i}\right)=\frac{q_{i}^{2}}{\sum_{i=1}^{n} q_{i}^{2}} \quad \text { lub } \quad k_{i}\left(r_{i}\right)=\frac{r_{i}^{2}}{\sum_{i=1}^{n} r_{i}^{2}}
$$

where:

$q_{i}$ - curvilinear correlation coefficient between feature $i$ and real estate price,

$r_{i}$ - linear correlation coefficient between feature $i$ and real estate price.

In the carried out analyses, it was assumed that the features that affect at least $5 \%$ of the price spread are considered to be significant. Thus, those for which the weight fraction of $k_{i}$ was smaller were considered negligible and marked in red in Table 3.

The results in Table 3 show that, in the majority of cases, the insignificance of selected features, indicated by linear correlation, is confirmed in the analysis of curvilinear correlations. However, the use of curvilinear correlation can significantly increase the number of features that de facto are considered significant in their impact on prices - up to $80 \%$, as in the investigated example, on the market of land intended for development. Pearson's correlations have identified 5 price-creating features, and curvilinear correlations up to 9. It is also worth pointing out how much the weight share of a given attribute can increase if we consider its non-linear relationship with the price of real estate on a given market. For example, such features of construction land as the placement of the property (its location) or its surroundings, which turned out to have $8 \%$ and $7 \%$ of shares respectively in explaining unit prices (column $k_{i}\left(q_{i}\right)$ in Table 3) after applying curvilinear correlations, were qualified as insignificant when using Pearson's correlations (column $k_{i}\left(r_{i}\right)$ of Table 3 ). This is all the more valuable because we know intuitively and from experience that the price of real estate is largely shaped by its location, though not necessarily linearly.

In Table 3, the features whose weight shares changed significantly after applying the curvilinear correlation analysis in relation to the Pearson correlation analysis are marked in yellow. For obvious reasons, they could not decrease in their absolute values after using nonlinear correlations $\left(q_{i}{ }^{2}\right.$ in relation to $r_{i}^{2}$ ), because the purpose of their application is to increase the degree of identification of price variability depending on a given feature. However, a decrease in the normalized share $\left(k_{i}\left(q_{i}\right)\right.$ relative to $k_{i}\left(r_{i}\right)$ ) may occur, which takes place for several features on the construction land market (Table 3): for example, the share of fashionability of a given location decreased from $10 \%$ to $8 \%$. Drops can be much higher than this. However, this does not change the fact that the square function chosen for this feature better illustrates its relation to price than the linear function $\left(q_{i}\right.$ in relation to $\left.r_{i}\right)$.

The opposite situation may also take place, when the feature significant from the beginning turns out to be even more significant when applying the curvilinear correlation analysis. An example is the type of access road to building plots, the share of which increased from $15 \%$ to over $21 \%$, when, instead of the linear matching for linking this feature with the land unit price, we used the homographic function. Figure 4 confirms the suitability of this type of function.

It may of course turn out that the attempt to match nonlinear regressions to the dependency feature - price will fail or not change much in the determined weights of market characteristics. The coincidence of the shares determined from two different types of correlations will then be indicative of the homogeneity of the examined real estate market. The heterogeneity of the analyzed land property market for construction purposes is confirmed by the large percentage of significantly different weight shares, after the application of curvilinear correlations (about 30\%), in relation to their equivalents resulting from Pearson's correlation analysis.

Finally, the estimated weight share for each property feature is higher than the results shown in Table 3. They do not take into account the adjustment of the shares $k_{i}$ after the final rejection of insignificant features so that they eventually add up to $1(100 \%)$. The adjusted values of weight shares, calculated only for the price-making attributes of real estate, are presented in Table 4 . This correction is also important due to the sum of the coefficients of determination, a too high value of which may also indicate the redundancy of features. 


\section{S sciendo}

Table 4

Comparison of the final weight shares of the price-creating features of land properties for development, calculated on the basis of curvilinear and linear correlations

\begin{tabular}{cccccc}
\hline$i$ & Real estate feature & $q_{i}{ }^{2}$ & $\begin{array}{c}k_{i}\left(q_{i}\right) \\
\text { adjusted }\end{array}$ & $r_{i}{ }^{2}$ & $\begin{array}{c}k_{i}\left(r_{i}\right) \\
\text { adjusted }\end{array}$ \\
\hline 1 & Destination in the local plan & 0.2021 & 0.081 & 0.1237 & 0.104 \\
\hline 2 & Communication access & 0.1847 & 0.074 & & \\
\hline 3 & Location of the property & 0.2613 & 0.105 & & \\
\hline 4 & Fashion for location & 0.2536 & 0.102 & 0.2450 & 0.206 \\
\hline 5 & The basic function & 0.1599 & 0.064 & & \\
\hline 6 & Total infrastructure & 0.2289 & 0.092 & 0.1907 & 0.161 \\
\hline 7 & Approach road & 0.6695 & 0.270 & 0.3524 & 0.297 \\
\hline 8 & Surroundings & 0.2094 & 0.084 & & \\
\hline 9 & Development & 0.3121 & 0.126 & 0.2752 & 0.232 \\
\hline & Sum: & $\mathbf{2 . 4 8 1 5}$ & $\mathbf{1 . 0 0 0}$ & $\mathbf{1 . 1 8 7 0}$ & $\mathbf{1 . 0 0 0}$ \\
\hline
\end{tabular}

Source: own study.

The results in Table 4 show a significant decrease in the sum of the coefficients of determination after the rejection of insignificant property features: from 3.13 to 2.48 taking into account nonlinear relations, and from 2.42 to 1.19 for linear correlations.

An important aspect of the entirety of considerations is also the excessive loss of information to which we are exposed considering only linear relationships in the feature-price pairs. The initial set of market data in the conducted analyses was described using 21 market characteristics. The analysis of the redundancy of the features and the study of their significance, taking into account only linear dependencies, reduced this set to 5 features, which is about $24 \%$ of their original number. On the other hand, taking into account non-linear dependencies allowed information that the 9 characteristics of real estate brings, i.e. $43 \%$ of the original set, to be maintained.

\section{Practice of applying nonlinear methods in determining the weights of market characteristics}

The presented analyses may seem too complicated for the average property appraiser. Like all more advanced tools, they certainly are not for everyone to use. However, taking into account the availability of various IT packages for statistical analysis on the market, it is worth overcoming the initial "resistance to the unknown" and using the school knowledge of graphical forms of elementary functions, to make an effort to more precisely determine the weights of market characteristics. The practice of related activities, described in detail in the previous chapter, can be summarized in the following steps:

a) depicting the dependence of the price on subsequent, identifiable real estate features - making scatterplots with a line depicting the dependence, optimally matched, imposed on each graph,

b) selection of non-linear functions to two-dimensional feature-price relationships, giving a chance for good matching,

c) estimation of the parameters of the tipped functions,

d) verification of the matching quality of the estimated two-dimensional models, using the determination coefficient and the choice of the best one,

e) calculation of weight shares based on the squares of curvilinear correlation coefficients.

In the above procedure, having access to the IT program used for statistical analysis - only point $b$ requires additional knowledge, which we apply to the program in the form of providing general formulas of typed non-linear functions. Having regard to the exemplary elementary functions listed in Table 2 - we can consider this general mathematical knowledge. The rest is done automatically. In this study, the author gives a detailed rule of conduct (Formulas (1) - (6)), due to the scientific nature of the publication.

It is obvious that the above analyses do not replace a separate study of the redundancy of real estate features due to their collinearity, or consideration of grouping data due to the presence of dichotomous features. In the presented example, dichotomic features, illustrated in Charts 6 and 7, turned out to be insignificant at the stage of calculating the weights of market characteristics, so grouping was not necessary. 


\section{Conclusions}

In this study, no detailed statistical comparison was made of the value $k_{i}\left(q_{i}\right)$ against $k_{i}\left(r_{i}\right)$, in the researched local market. This can be done using standard statistical tools, such as interval estimation or parametric significance tests (GREN 1978). However, this was abandoned because we are not concerned here about making general conclusions regarding the usefulness of nonlinear correlations on the markets of certain types of real estate or in relation to specific attributes. The present work is only about signaling the problem of the effects of excessive simplification in the approach to the real estate market analysis, which should be an inherent element of any real estate valuation (Regulation 2004). The examples are intended to show how the conclusions of such analysis can change when we use a bit more sophisticated tools to carry it out. Considering the generally accepted accuracy of determining the weight shares of features in explaining the price spread, the obtained results allowed for a visual presentation of the differences between the linear and non-linear approach to the description of the feature-price relationship. This approach may be particularly useful when the number of features considered as significant with traditional, linear methods is so small that the sum of their absolute weights is much lower than 1 . This may indicate information deficiencies and result in a distorted valuation result at a later stage. The study of non-linear relationships has a good chance of being an effective remedy for the excessive reduction of market data.

\section{Bibliography}

ADAMCZEWSKI Z., 2011, Elementy modelowania matematycznego wwycenie nieruchomości, Podejście porównawcze, (Elements of Mathematical Modelling in Real Estate Valuation, a Comparative Approach), Oficyna Wydawnicza Politechniki Warszawskiej, Warszawa Publishing House of the Warsaw University of Technology, Warsaw).

BARAŃSKA A., 2010, Statystyczne metody analizy $i$ weryfikacji proponowanych algorytmów wyceny nieruchomości, WYDAWNICTWA AGH, KRAKÓW (Statistical Methods for the Analysis and Verification of the Proposed Algorithms in Real Estate Appraisal Publications agh, krakow).

BITNER A., 2010, O użyteczności metod statystycznych w wycenie nieruchomości, Polska Akademia Nauk, Kraków, Komisja Technicznej Infrastruktury Wsi, nr 12 (On the Usefulness of Statistical Methods in Property Valuation. Polish Academy of Sciences, Krakow, Technical Committee of Rural Infrastructure).

Cellmer R., 2014, The Possibilities and Limitations of Geostatistical Methods in Real Estate Market Analyses, Real Estate Management and Valuation, Vol. 22, No. 3, pp. 54-62.

CELLMER R., SzCZEPANKOWSKA K., 2015, Use of Statistical Models for Simulating Transactions on the Real Estate Market, Real Estate Management and Valuation, Vol. 23, No. 2, pp. 99-108.

CZAJA J., 2001, Metody Szacowania Wartości Rynkowej i Katastralnej Nieruchomości. KOMP-SYSTEM, Kraków (Valuation Methods of Market and Cadastral Value of Real Estate. KOMP-SYSTEM, Krakow).

DosZYŃ M., 2017, Statistical Determination of Impact of Property Attributes for Weak Measurement Scales. Real Estate Management and Valuation, 25(4), pp. 75-84.

DOsZYŃ M., GNAT S., 2017, Econometric Identification of the Impact of Real Estate Characteristics Based on Predictive and Studentized Residuals, Real Estate Management and Valuation, Vol. 25, No. 1, pp. 8492.

GACA R., SAWIŁOW E., 2014, Zastosowanie wspótczynników korelacji rang Spearmana do ustalenia wag cech rynkowych nieruchomości, Rzeczoznawca Majątkowy, nr 82, pp. 24-30 (Application of Spearman's Rank Correlation Coefficient for Establishing Ranks of Real Estate Characteristics, Real Estate Appraiser, No. 82, pp. 24-30).

GREŃ J., 1978, Statystyka matematyczna, modele i zadania, Wydawnictwo Naukowe PWN, Warszawa (Mathematical Statistics, Models and Tasks, Scientific Publishers PWN, Warsaw).

MALETA M., 2013, Methods for Determining the Impact of the Trend in the Valuation of Land Property, Real Estate Management and Valuation, vol. 21, no. 2, pp. 29-36.

MCAllister P., 2007, Valuation Accuracy: A Contribution to the Debate, Journal of Property Research, Vol. 12, Issue 3, pp. 203-216.

NúÑEZ TABAles J., Rey CARMONA F., CARIDAD y OCERIN J. Ma.., 2013, Implicit Prices in Urban Real Estate Valuation, Revista de la construcción, Vol. 12, No 2, pp. 116-126.

Rozporządzenie Rady Ministrów z dnia 21 września 2004 r. w sprawie wyceny nieruchomości $i$ sporzadzania operatu szacunkowego. Dz. U. nr 207, poz. 2109 z późniejszymi zmianami (Regulation of 
the Council of Ministers of 21 September 2004 r. on Real Estate Valuation and Estimation. Journal of Laws no 207, item 2147 with later changes).

SANCHEZ-RodrigueZ M. I., 2014, Modeling and Partial Least Squares Approaches in OODA. Biometrical Journal, Vol. 56, No 5, pp. 771-773.

SAWIŁOW E., 2010, Problematyka określania wartości nieruchomości metodą analizy statystycznej rynku (The Problems of Qualifying the Value of Real Estate with the Method of the Statistical Analysis of the Market), Studia i Materiały Towarzystwa Naukowego Nieruchomości, Vol. 8, No. 1, pp. 21-32.

Zavadskas E. K., TURSKIS Z., Ustinovichius L., SHevchenko G., 2010, Attributes Weights Determining Peculiarities in Multiple Attribute Decision Making Methods, Inzinerine Ekonomika-Engineering Economics, vol. 21, nr 1: 32-43.

Ustawa o gospodarce nieruchomościami z dnia 21 sierpnia 1997 r. tekst jednolity: Dz.U. 2016, poz. 2147 (Act of 21 August 1997 on the Real Estate Economy, Journal of Laws, 2016, item 2147, as amended). 